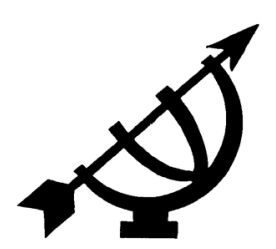

\title{
Towards a theory of presuppositions: Kuyperian contributions
}

\author{
R. Coletto \\ School of Philosophy \\ Potchefstroom Campus \\ North-West University \\ POTCHEFSTROOM \\ E-mail: renato.coletto@nwu.ac.za
}

\begin{abstract}
Towards a theory of presuppositions: Kuyperian contributions

One of the most important themes of contemporary philosophy of science was the discovery of presuppositional beliefs and frameworks as factors influencing scientific research. This article explores the development of a theory of presuppositions within Kuyperian philosophy. The authors discussed in this study represent a few Kuyperian families: Dooyeweerd, Vollenhoven (briefly), Wolterstorff, Klapwijk, Duvenage and Botha. The perspective is both historical and systematic. Historically, it refers to the main authors who contributed to establishing the basic features of such a theory. Systematically, the article tries to evaluate the proposals of each contributor by assessing their value and limits. In doing so, the author often defends his own preferences and indicates the directions to be followed.
\end{abstract}

\section{Opsomming}

\section{'n Teorie van vooronderstellings: Kuyperiaanse bydraes}

Een van die belangrikste temas van die huidige wetenskapsfilosofie is die ontdekking van vooronderstellings, aannames en raamwerke as faktore wat wetenskaplike navorsing kan beïnvloed. Hierdie artikel verken die ontwikkeling van 'n teorie van vooronderstellings binne die Kuyperiaanse filosofie. Die outeurs wat in hierdie studie bespreek word, verteenwoordig enkele Kuyperiaanse families: Dooyeweerd, Vollenhoven (kortliks), Wolterstorff, Klapwijk, Duvenage en Botha. Die perspektief is sowel histories as sistematies. Histories word na die belangrikste outeurs verwys wat 'n bydrae gelewer het om die basiese kenmerke van so 'n teorie te vestig. Sistematies probeer die 
artikel om die voorstelle van elke bydraer te evalueer deur hulle waarde en grense te meet. In die proses verdedig die outeur in baie gevalle sy eie voorkeure en dui die rigting aan wat gevolg behoort te word.

\section{Introduction}

Twentieth-century philosophy of science has discovered the importance of presuppositions and debated about premises (Polanyi, 1946), frameworks (Popper), paradigms and worldviews (Kuhn). In a previous article I (Coletto, 2007) explored the development of a theory of presuppositions in contemporary (humanist) philosophy of science. In the present article I explore the same topic within Christian (more precisely: Kuyperian-reformed) philosophical circles. I (Coletto, 2007:595 ff.) have already sketched some lines of comparison between the two schools, therefore I will not return to that topic. 1 In the following pages I would rather like to focus on (what I consider) the strong and weak points of several Kuyperian contributions in this field.

Before proceeding, it is necessary to specify the meaning of a few terms appearing in the title. Although there is a scientific type of presuppositions (e.g. axioms and theorems) in this article, the term presuppositions/nal always refers to pre-scientific presuppositions including all types of beliefs, clusters of beliefs, frameworks, ground motives and so on. The term scholarship is also used in an inclusive sense, indicating both philosophy and all special disciplines (often distinguished as humanities and natural sciences). Finally, the term Kuyperian (a synonym of neo-Calvinist) includes several philosophical families, for example the reformational one (Dooyeweerd, Vollenhoven and others), the school of reformed epistemology (Wolterstorff, Plantinga and others) or the specific current initiated in South Africa by H.G. Stoker.

In the following pages, the authors who have supplied the most relevant contributions to the present topic are discussed in historical order. Trying to include representatives of several branches of the Kuyperian family (and different generations as well) I will focus on

1 One of the differences between the two approaches emerges in the following pages. In contemporary philosophy of science, presuppositions (e.g. paradigms) are discussed especially in relation to the natural sciences. In the reformational tradition presuppositions are also related to philosophy and the humanities. 
Dooyeweerd (and briefly Vollenhoven), Wolterstorff, Klapwijk, Duvenage and Elaine Botha, to whom this article is dedicated.

As mentioned previously their approaches are outlined and evaluated, thus evidencing (what I consider) some of their pros and cons. In this process my own preferences and recommendations will emerge as well. Let us start our exploration, therefore, from the work of Herman Dooyeweerd.

\section{Dooyeweerd}

\subsection{Religious ground motives}

The great turning point in Dooyeweerd's philosophy was the discovery of religious ground motives underpinning and conditioning the development of philosophic and scientific thinking (Dooyeweerd, 1984:iv ff.). This discovery was fundamental. On the one hand it revealed the inner link between religion ${ }^{2}$ and theoretical thinking. On the other hand it allowed rejecting the idea that scholars can be divided in two parties: the religious and the non-religious (i.e. the non-prejudiced, objective) ones. Dooyeweerd's achievement placed everyone in the same boat (that of religious conditioning) and clarified that scholarship is structurally the same for all parties involved.

Dooyeweerd started studying presuppositions and observing their function in scientific research in the 1930s. In those years a similar project was endorsed by Polanyi (1946:42 ff., 63 ff.). ${ }^{3}$

2 Dooyeweerd's use of the term religion/ous does not refer only to the "classical" religions like Christianity or Islam. It includes also the basic commitments of all those who "interpret" life in some way or the other (i.e. all human beings: humanists, atheists, positivists, Marxists, etc.). Along this line Clouser (1991:2223) argues that "a belief is religious if it is a belief (1) in something(s) or other as divine or (2) a belief concerning how humans come to stand in proper relation to the divine". As Clouser defines divine as "having the status of not depending on anything else", it is clear that all human beings have religious beliefs about some ultimate reality (e.g. matter, rationality, etc.).

3 As far as chronology is concerned, Hart (1985:145) points out that Dooyeweerd started the process of the recognition and study of presuppositions a few years before Polanyi. Polanyi (1946:42) distinguished two classes of presuppositions, which he called "general" and "particular assumptions", as well as a third type called "ideals" (e.g. Polanyi, 1946:71). He had a keen sensitivity for the presence of fundamental commitments of a fiduciary nature in all philosophical systems. 
According to Dooyeweerd $(1984,1: 68)$, the influence of religious motives on theoretical thinking is channeled via a threefold fundamental idea, which he calls a transcendental (or ground) idea. The latter answers three fundamental questions at the very sources of philosophy. The first one is the question concerning the origin of meaning. The second one deals with the unity (or multiplicity) of meaning and the third one deals with the relation of coherence and diversity between the different aspects of created reality (Dooyeweerd, 1984, 1:93-102).

These three questions are interrelated. According to Dooyeweerd (1984, 1:69), acceptance of a unique Origin of all meaning (or of two original principles opposed to each other) determines whether one accepts or not accepts (see second question) the integral unity of meaning at the root of the modal aspects. The answer given to this second question determines how one understands the mutual relation and coherence of meaning of the modal aspects. All this influences philosophical thinking, but also the special sciences.

\subsection{Sketching Dooyeweerd's model}

Basically, Dooyeweerd identified two pre-scientific frameworks: religious ground motives and worldviews. Two questions may be asked: what is the difference between these two frameworks and how are they positioned (i.e. what role do they play) in Dooyeweerd's model?

Concerning the first question, the main difference between a ground motive and a worldview lies in the fact that the former implies a claim to universal validity which the latter doesn't contain. The example of Christianity may clarify this point: for the Christian a religious ground motive is the heart of the Bible itself, namely the motif of "creation fall and redemption in Jesus Christ, through the power of the Holy Spirit" (Dooyeweerd, 1966:14). On the other hand, the particular worldview of a particular Christian community (e.g. the worldview of the neo-Calvinists of the nineteenth century in the $\mathrm{Ne}$ therlands) may be subjected to revisions, alterations and corrections, precisely in the light of the biblical revelation. Worldviews originate in the daily interaction with a particular community and cultural context, in a certain time and place. Their truth-claims are more modest. On the other hand, e.g. the biblical ground motive cannot be subjected to changes or revisions, and its truth-claims are universal in nature. 
This does not mean, of course, that the scientific elaborations of a Christian academic community (stemming from the biblical ground motive) are infallible. One has to distinguish between the ground motive of the biblical religion and the fallible, relative academic achievements of a person (or community) committed to that ground motive (Dooyeweerd, 1959:69-73). This is true for both natural sciences and humanities.

Concerning the second question (about the position or function of the two frameworks in this model), Wolters (1989) offers a fine study on different solutions adopted in different Christian traditions. In his view Dooyeweerd elaborated an original solution: philosophy and worldview are like two trees, both planted on the common soil of religious commitment. One may agree with Wolters that in this scheme a worldview flanks philosophy while a religious motive is their common ground or soil.

With a change of metaphor, we may say that in the Dooyeweerdian model knowing activities follow two parallel paths. All types of knowledge are connected to a religious ground motive (which does not mean it is strictly determined by it). However, science develops through philosophy and specialises in the particular disciplines (which study the world through modal perspectives). Everyday (or naive) knowledge develops via a worldview and focuses on concrete events and entities.

The two paths are not necessarily one-way (in the sense that the special sciences influence philosophy too), but the initial emphasis was mainly on the influence of ground motives on philosophy and of philosophy on the special sciences. The reason was that, in those years, positivism was still the main school in philosophy of science and it was therefore important to highlight the influence of presuppositions and of metaphysics on science.

One should notice that in his model Dooyeweerd does not place a worldview between ground motive and philosophy, as having a mediating role. The reason is that such a move would take us in the direction of relativising and historicising Christian scholarship. If one keeps in mind the different natures of ground motives and worldviews, it must be admitted that Dooyeweerd's decision is quite judicious (we will return on this issue later).

In conclusion one may ask whether, in the Dooyeweerdian model, worldviews have no contact whatsoever with philosophy (and the special sciences). In section 5 Klapwijk's answer to this question will 
be examined. In my opinion the possibility should not be completely excluded. In fact, worldviews keep "flanking" philosophy. It may be a kind of secondary relationship, but it seems to me that the two "trees" may still "pollinate" each other.

Dooyeweerd's contribution set the tone for the continuation of the debate.

\section{Vollenhoven}

Vollenhoven explores the similarities and differences between scientific and non-scientific thinking, and he studies the characteristics of worldviews, but he does not propose dramatic alterations to Dooyeweerd's views on presuppositions. When his model is illustrated in a scheme (cf. Kok, 1988:116) it looks quite similar to the one developed by the Dooyeweerdian school, with one difference: the role of religious ground motives is not equally prominent or relevant.

Klapwijk (1987:107) points out that Vollenhoven was never too fascinated by the idea that we need a bridge between the Bible and Christian scholarship. Let us go back to the classical locus in which Vollenhoven sets the tone for our discussion:

If you believe God's Word, and trust that Word, you obtain a philosophy the basis of which is formed by that non-philosophical, non-scientific belief in Holy Scripture and in God. (Vollenhoven, 1953:8; 1992:103.)

Vollenhoven remained equally lukewarm towards the idea that a ground motive could concentrate in itself the whole biblical revelation. How can the richness of the Word be included in a formula? It could be argued that this attitude favoured the habit of quoting the Bible with more freedom in the context of philosophical argumentations, but this remains a debatable issue.

One should also notice that in more recent times several academics in the Vollenhovian school have provided valuable contributions by exploring especially the role of worldviews. One should mention, for example Van der Walt (2008), Wolters (1989) and Olthuis (1989), whose contributions in this field are well known. The work of these authors, however, does not aim primarily at introducing radically new insights, but especially (though not exclusively) at systematising and applying the work already done in this field.

But let us proceed with order. After Dooyeweerd and Vollenhoven some time elapsed before someone decided to revive the discussion 
on presuppositions, although one can say it was never abandoned. For a while, the discussion seemed to be settled. Stoker did not propose different items or arrangements. The second generation of reformational thinkers (Mekkes, Popma, Zuidema) did not write much on the topic. A text by Van Riessen (1973) did not add particular novelties to the debate. The one who threw the next stone in the dam was Nicholas Wolterstorff.

\section{Nicholas Wolterstorff}

\subsection{The idea of "control beliefs"}

Wolterstorff (1976) started to propose his innovative views on presuppositions and scholarship in his book, Reason within the bounds of religion. He was a philosopher influenced by neo-Calvinism (Wolterstorff, 1989:68), but also by Scottish Commonsense Realism (Thomas Reid and others), which is still quite influential in today's North American Presbyterian circles (cf. Vander Stelt, 1990).

Wolterstorff's renewal of a theory of presuppositions is mainly channelled through the idea of control beliefs. What type of beliefs are they? Concerning their function, they control the selection of theories which are acceptable to a specific scholar (Wolterstorff, 1976: 63). They also help devising new theories in the sense that they lead the scholar in the process.

Christians, committed as they are to human responsibility, are thereby also committed, as I see it, to human freedom; which means they will reject purely deterministic accounts in the social sciences and search for non-deterministic accounts. (Wolterstorff, 1989:76.)

Concerning the nature of control beliefs, Wolterstorff says they should be selected among the beliefs constituting the authentic religious commitment of a Christian. On this point, however, some have experienced a difficulty. In fact, Wolterstorff (1976:70) also argues that this authentic commitment varies from person to person and from time to time. Eventually, says Wolterstorff (1976:71), someone should insist that there must be propositions that are part of everybody's Christian commitment in all times. These propositions must be few and simple. As it may be expected, some considered such a fluctuating view of the Christian religion as rather problematic. For example, Venter (1994:279) sharply remarked that if this is the case "it does not make sense to call anything 'Christian' any longer". 
A most important characteristic of control beliefs, according to Wolterstorff (1989:76), is that they constitute the true "point of connection between faith and learning". 4 Neo-Calvinist philosophy, in his view, has suggested several other candidates which could account for this link, but without success. In particular, Wolterstorff (1989:67 ff.) rejects the idea that worldviews or faith may perform the linking task.

But are control beliefs better candidates to connect faith and scholarship? One may argue, for example, that even after the introduction of control beliefs it might still be possible to adopt theories that are quite at odds with one's basic commitment (e.g. by emphasising one belief instead of another). We have seen, for example, that Wolterstorff (1989:76) emphasises human freedom as a guideline for the Christian reflection in the social sciences. However, the Humanist arsenal is full of theories in which the ideal of freedom 5 plays a fundamental role. Will Christian sociologists simply accept them? And which ones will they prefer? Wolterstorff might reply that there are other beliefs assisting in the selection of theories. ${ }^{6}$ Unfortunately he also admits that they are not particularly related to one's Christian commitment (Wolterstorff, 1976:77-79).

\subsection{Beliefs or frameworks?}

The above discussion points towards the idea that single beliefs might be too light to support Christian learning. Something more solid may be necessary, something like the frameworks recognised by the reformational group. Duvenage (1985:35) too regards the control

4 The essay, On Christian learning (Wolterstorff, 1989), dealing to a large extent with control beliefs, was republished with the title The point of connection between faith and learning (Wolterstorff, 2004:64-86).

5 According to Dooyeweerd the ideal of freedom corresponds to one of the two poles constituting the Humanist ground motive (the two poles are "nature" and "freedom").

6 Control beliefs are not the only beliefs acknowledged in Wolterstorff's theory of theorising. He also mentions data beliefs and data-background beliefs (Wolterstorff, 1976:61-64). Data beliefs are beliefs about the entities within the scope of a theory (Wolterstorff,1976:61). Data-background beliefs constitute the conditions for accepting certain data beliefs (Wolterstorff, 1976:63-64). In this way Wolterstorff classifies beliefs into three fundamental categories. Regarding this "triad", Hart (1988:30-31, footnote 25) observes that they constitute something not much dissimilar from Polanyi's tacit, focal and committed dimensions of knowing. 
function as essential, but points out that it is normally attributed to worldviews or similar frameworks.

Indeed, Wolterstorff mentions beliefs more often than frameworks (cf. footnote 6). It is also true that he mentions actual and authentic Christian commitment, but they can be understood as the sum total of the individual beliefs by which they are constituted. It is interesting to read his Educating for responsible action (Wolterstorff, 1980) in which he uses only one belief (i.e. the biblical idea of responsibility) to outline a whole theory of education, in neat distinction from several other (secular) approaches.

The achievement is amazing, one must admit. Yet one cannot help wondering why is responsibility preferred to other, equally important Christian principles or beliefs. Why only one belief and why this one? Is it possible to imagine that other beliefs may be equally relevant? What helps selecting such beliefs? In other words, in order to avoid an atomistic view of presuppositions, the role of frameworks calls for attention. Let us proceed examining the topic of the characteristics of beliefs.

\subsection{Focusing on the function}

When it comes to understanding beliefs and presuppositions, Wolterstorff $(1976: 65,81)$ especially emphasises their function. Function or role seems to be more fundamental than nature or content, as the same belief may assume different functions in different theories or contexts, depending on the role it plays, on how it is held.

This path of research has been explored for example by Stephen Wykstra, a scholar in this tradition. Wykstra (s.a.:10-12) shows that if we mainly look at the content it is difficult to distinguish metaphysical beliefs from religious beliefs, for example. We should rather pay attention at how beliefs are held (Wykstra, s.a.:13). However, during his demonstration another factor emerges, namely the importance of the context in which beliefs originate and are elaborated. In fact, according to Wykstra, metaphysical beliefs "rest on a highly intellectual cognitive enterprise", while religious beliefs "arise more existentially getting their primary sustenance from within the religious and spiritual life" (Wykstra, s.a.:14). I would, therefore, agree that the function is not all. The origin or context of elaboration is also important. What about the content (i.e. what beliefs are about)?

Wykstra (s.a.:7) rejects Clouser's solution (cf. footnote 2) that a belief is religious when it is about the divine. Although Clouser has 
distanced himself from the idea that religious beliefs have a specific content (i.e. they are about gods, holy books, rituals, etc.), his solution still insists on content, in the sense that religious beliefs are invariantly about the divine. In this regard Wykstra (s.a.:13) re-conducts us to how and why beliefs are held.

However, I would not exclude that "how" and "why" may be complemented by "what". Clouser's argument that those beliefs are invariantly about what is considered non-dependent on something else is quite compelling. This approach may be compatible with the preoccupation concerning the context (or origin) and, I would say, also the questions concerning the nature of beliefs should not be neglected.7 My view is that, in order to understand presuppositions all the factors should be considered: the nature, the content, the role they play, the context of elaboration and so forth.

\subsection{Positive contributions}

I would like to conclude this section by mentioning what I consider the most positive side of Wolterstorff's contribution to a theory of presuppositions. First of all, Wolterstorff identifies several new types of beliefs and clarifies their functioning. As a matter of fact, after reading Wolterstorff, one realises the complexity of theorising, the multiplicity of presuppositions and interactions. In Wolterstorff's model, one is confronted with a dynamic element which is missing in other models.

For example, Wolterstorff (1976:72; 1989:77-79) has successfully suggested that a Christian view of scholarship should not be unidirectional or expressivist. In other words, one should avoid focusing only on the influence of beliefs on scholarship, as if it was a one way direction or as if scholarship may simply be an expression of the beliefs and commitments of a community. Theories too influence our worldviews and beliefs. Science develops through many paths and directions, in a complex and continuous interaction of epistemic factors.

7 In a rather sharp footnote Hart (1983:246, footnote 57) writes that "for Wolterstorff no control belief is essentially a control belief, depending on its role in inquiry". He refers to the problem that Wolterstorff especially focuses on the function of beliefs. Furthermore, Hart (1983:232) asks:

Are there confessional beliefs that are essentially ultimate, and are there rational beliefs that are never capable of being legitimate confessional beliefs at least for a Christian? 
One can learn from Wolterstorff that by focusing on a single epistemic player (for example a worldview) one can hardly explain a complex activity such as the devising and weighing of theories. Although I would like to avoid the atomisation (so to speak) of worldviews (or religious motives) into many single beliefs, I suspect that the presuppositions involved in the scientific elaboration of theories might interact in more complex and dynamic ways than reformational philosophy has admitted up to now. 8

\section{Jacob Klapwijk}

\subsection{The mediating role of worldviews}

Klapwijk made several important contributions to the present discussion. He pleaded for more communication and exchange of ideas. Klapwijk (1986:143, footnote 9) stated quite clearly, for example, that he doesn't like Kuhn's view of worldviews (i.e. paradigms) in which ideas are basically held captive within a certain framework and cannot be communicated to those who argue from within another cage. Klapwijk (1986) prefers to think that ideas can be offered, exchanged, transformed and eventually appropriated.

On the other hand, Klapwijk pleaded for a more hermeneutic attitude. He, therefore, suggested that worldviews should not be relegated to the side of religious ground motives. Worldviews should be regarded as mediators between fundamental commitments and scientific elaborations. In other words, worldviews have a mediating role to play between religious ground motives and theoretical thinking (Klapwijk, 1987:108).

Klapwijk's intellectual honesty led him to admit that the proposed move represented a new direction within reformational philosophy, one which could legitimately prompt the concerns of fellow philosophers. In fact, he (Klapwijk, 1987:109) recognised that the introduction of worldviews as mediators might have the effect of relativising one's position, of reducing its claim to universal validity (cf. section 2.2). Also, the advantage which Klapwijk wanted to achieve is that such an arrangement makes philosophy more hermeneutic, in

8 I have discussed a few other aspects of Wolterstorff's philosophy of scholarship in two different articles. Concerning the relationship between the devising and weighing of theories, see Coletto (2009:401-405). On the influence of theorising on religious commitment, see Coletto (2010a:20-21). In the latter article one finds comments on several of Wolterstorff's critique to the reformational philosophy of scholarship. 
other words more capable of dealing with the here and now, with concrete problems, the struggles of concrete people which may be lost in a more universal approach.

\subsection{Ground motives and worldviews}

Another interesting proposal from Klapwijk concerned the religious ground motives. In his view, what Dooyeweerd indicated as ground motives, were in fact worldviews (Klapwijk, 1987:109). According to Klapwijk, Dooyeweerd borrowed the idea of ground motives from Kuyper, who spoke of several fundamental life-systems. Concerning the western world, Kuyper discussed four of them: paganism, Roman Catholicism, modernism and Calvinism (the most consistent expression of the biblical life view). Klapwijk argues that Dooyeweerd must have drawn the idea from there, for he also presents his four systems, with the difference that under his pen they became religious. ${ }^{9}$

At this point, however, a question emerges: Do ground motives need the mediation of worldviews or are they worldviews? Klapwijk has defended both theses, but on this point a choice seems to be necessary, as one thesis excludes the other.

\subsection{Sequentiality and consistency}

Klapwijk discussed many presuppositional frameworks and this is indeed a merit. However, here we have to notice an inclination to present them in a way which displays a clear sequentiality. In other words, it is difficult to avoid the impression that those frameworks are placed in a sequence, one after the other. They look like the rings of a chain, each one connected to the previous and to the following one (but without much connection to the others). The problems related to mediation were already mentioned by Dooyeweerd (1959:66) and Geertsema (1987:146) discusses the same issue in relation to Klapwijk.

We may define sequentiality as the inclination to multiply the mediators. Klapwijk's (1984:166) list includes "one's religious commitment, personal conception of life, worldview and the practical ethos of

9 Although it does not constitute a refutation of Klapwijk's argument, one might observe that the ground motives explored by Dooyeweerd are at least five. In fact, he discusses the ground motive of Roman culture as well (Dooyeweerd, 1980:22 ff.). 
one's community". (The chain continues at the scientific level with the mediation of philosophy!)

A study clarifying which frameworks play an active role in scholarship (eventually which terms are simply synonyms) and what function they are supposed to have, would be desirable. I also auspicate that Klapwijk's old and new proposals may be connected and sorted out so that a clearer picture may emerge. Klapwijk's writing range over more than four decades. Across the years some proposals were abandoned, others were modified and I, for one, have difficulties tracing a coherent development of the different ideas.

In more recent times the discussion about religious ground motives seems to have been substituted (e.g. Klapwijk, 2008:200) by a discussion about faith. One may wonder whether the distinction between (modal) faith and (central) religion - a leading star for neoCalvinist philosophy - has been abandoned too. Concerning worldviews for example, in some cases they are said to "derive from faith" (Klapwijk, 2008:196), while in others they are the result of "religious expectations" (Klapwijk, 2008:205). Still in other cases (Klapwijk, 2008:200, fig. 10.1) worldviews disappear from the picture and scientific thinking seems to interact directly with faith/religion. Even in this case, therefore, a good clarification of Klapwijk's views, in which past and present arguments are connected, would be a good service to our theory of presuppositions.

In my view the best contribution by Klapwijk in this field remains the idea that worldviews have something to do with scientific reflection. This is something more than Dooyeweerd was prepared to admit. Their influence, therefore, should be recognised and regulated, rather than ignored or denied. The way Klapwijk has tried to achieve this result (i.e. by making worldviews mediators), has raised several objections. However, the basic idea, in my opinion, remains valid and should be pursued further.10 My guess is that, if the chain or mediation metaphor (or the concentric circles of Klapwijk, 2008:200, fig. 10.1) could be substituted by a more dynamic one, many elements in Klapwijk's model would fall into place. In this respect,

10 I have discussed other aspects of Klapwijk's philosophy of scholarship in different sections of a few articles. For example, concerning his view of the role of biblical perspectives in Christian scholarship, see Section 5 in Coletto (2010b). Concerning his view of interaction with non-Christian scholarship, see Coletto (2010a:12-16). 
something can be learnt from a South African scholar working in the tradition of H.G. Stoker.

\section{Benonie Duvenage}

Good ideas do not only come from Europe or North America. In the mid 1980s a brief but extremely interesting sketch of a theory of presuppositions was presented in South Africa by Duvenage (1985). The latter devised a model in which the problem of sequentiality seems to be drastically reduced and the interaction of the different epistemic players becomes much more dynamic. He represents the scientific process through the image of a spiral, in which three levels or foci are identified. On the wider part of the spiral is the macrofocus, followed by a mesofocus and by a microfocus at the bottom (narrower) part of the spiral.

Following this model, a scholar should take into account that the levels of scientific investigation are many, but connected to each other (Duvenage, 1985:31-36). The scientist can move from one level (focus) to another and back again. In each level we find relevant reference points or, as Duvenage calls them, "perspectives" or "visions" (Duvenage, 1985:33).

What are the relevant perspectives in each context? I will simply quote Duvenage's (1985:34) sketch.

Microfocus: scientific knowledge of a discipline (e.g. economics). Pre-knowledge about the field investigated. Knowledge about the status of research in the relevant field.

Mesofocus: relevant Scriptural data (e.g. stewardship). Philosophy of the particular discipline (e.g. economics). Theories about the field (e.g. behaviorism).

Macrofocus: Scriptural perspectives. Convictions of lifeview. Philosophical points of departure (e.g. ontology, anthropology, doctrine of society).

Interesting in this model is that on each level one finds scientific and pre-scientific players interacting. The nature of the different players is not blurred, yet elements that are often considered mediators (e.g. philosophy, worldviews) are regarded as interacting together at different levels, in a model which is convincingly dynamic.

One may still object that in Duvenage's system the channels to be followed are prescribed a bit rigidly, or according to a prefixed sequence. The spiral metaphor tends to soften the sequentiality, but 
one may wonder whether a certain hierarchic arrangement does not remain. In other words, one may, for example, still ask the question whether the convictions of life view (which are operative at macrofocus level) are also directly available to the special sciences (microfocus) or only through the philosophy of a particular discipline which operates at the mesofocus level.

When Duvenage (1985:37-38) says that scriptural perspectives must first be elaborated into an ontology before they can play a role in scholarship, he seems to prescribe a certain rigidity in the sequences to be followed. Duvenage's scheme should be clarified a bit more, but I consider it quite valuable in many respects.

This model portrays scholarship as a kind of network of epistemic factors. An objection which is often raised in such cases, is that the traditional role of some epistemic players simply gets lost and in the end all the players join in a sort of undifferentiated carnival. On this point Frame (1987:89) reminds us that we don't need to flatten our epistemological views by supposing that all the presuppositional frameworks (and disciplines) operating in a certain system have the same function and authority. Duvenage (1985:18) agrees with this view and shows that, even in his dynamic model, the specific functions of the epistemic players don't need to be blurred.

Let us now complete our survey by considering Elaine Botha's contribution.

\section{Elaine Botha}

Elaine Botha renewed the discussions in this field by focusing especially on the role of metaphors in science. I must admit that it is a territory which is less familiar to me. A much more extensive study would be necessary to survey her work in those fields and to trace the numerous connections with the work of Boyd, Kuhn, Black, Johnson, et cetera. Nevertheless, metaphors do not exclude the presence of presuppositional frameworks. On the contrary, they presuppose it. I will, therefore, attempt a few notes on her work on presuppositions.

In a specific text Botha (2002:214) indirectly provides a list of the epistemic players which she recognises and considers relevant in relation to theorising. They are one's fiduciary commitment, a worldview and, on the scientific side, philosophy, a scientific worldview and the special sciences. This is the basic Dooyeweerdian approach with something new, namely the idea of a scientific worldview. Here 
Botha (2002:214, footnote 2) seems to have something similar to Kuhn's paradigm in mind. In fact, Kuhn speaks of revolutions as worldview changes and his paradigms/worldviews are at least in part scientific.

On the reformational side Stafleu (1987:242-249) also supports the idea of a scientific worldview. Unfortunately, on this point they both provide limited information and one would definitely like to learn more. Some of the questions arising might be the following: Is a scientific worldview supposed to be back-up only by the natural sciences (as Kuhn's paradigms)? What about the humanities? Do they also have their scientific worldview? What would Botha reply to those philosophers (e.g. Strauss, 2009:196) who regard philosophy itself as a scientific worldview? She seems to have this issue in mind in Botha (2007:214). We can only trust that Botha will explain the idea further at a later stage.

I regard Botha's contribution as being fundamentally Dooyeweerdian/reformational. From Dooyeweerd she has inherited the very basic idea that religion 11 works, not only before science, but within science. This is an insight which shapes her approach in a fundamental way. In fact, by arguing that fiduciary presuppositions work within science, she endorses the strong thesis according to which not only science and scholarship are influenced by philosophical assumptions, but the latter are expressions of ultimate religious commitments (Botha, 2007:181). While many would grant that religion parallels or precedes science she follows the reformational tradition along the path leading to the inner reformation of scholarship.

Yet, Botha has often incorporated several lessons by predecessors and colleagues from other Kuyperian families in her approach. Lack of space prevents me from mentioning her appreciation of insights from Van Riessen or Stoker. Let us only mention her interaction with Wolterstorff's idea of control beliefs (e.g. Botha, 2006:28-30). She has often shown appreciation for that idea. At the same time, however, she is careful not to reach an atomistic conception of such beliefs and therefore she insists that clusters and even hierarchies of beliefs should be recognised (Botha, 2007:212-214). One should be careful not to be unilateral or partial in one's approach.

11 On the nature of religion, Botha follows the Dooyeweerd-Clouser path (footnote 2) without losing sight of the distinction between (central) religion and (modal) faith. In particular she (e.g. Botha, 2007:140) distinguishes between a narrow and a broader sense of religion. 
Furthermore, although she agrees with Wolterstorff that the function of beliefs is very important, she acknowledges that sometimes control beliefs assume (illegitimately) the role of religious beliefs. At this point she introduces a distinction: while this operation is possible in practice, it is not automatically legitimate. Holding those beliefs as religious beliefs, constitutes a transgression of the proper nature and role of those beliefs, an absolutisation in which they become myths (Botha, 1996; 2007:154). While her understanding of religion allows her to include those positions within the religious ones, she does also discern a normative and an anti-normative use of beliefs (Botha, 1993:44).

Finally, there is a special skill to be admired in Botha's contribution, namely the ability to connect reformational ideas and terms to terms and ideas already used in humanist and secular circles. Many of the terms she uses, e.g. root-metaphor and conveyance are borrowed from that environment and placed in a reformational perspective. I think this has the advantage of creating bridges of dialogue and interaction.

That this is also risky, has been said many times and it is true: one cannot simply formally deal with philosophical ideas. In time they might reveal like the Trojan horse their hidden and lethal implications. But then, any investment implies a risk. If the alternative is burying one's talents under the ground, Elaine Botha has preferred trading in new territories. As far as I can see, she has adopted an approach which may be called "convivial", but never becomes eclectic. She has preserved her presuppositional and philosophical identity, which is the only solid basis for genuine dialogue.

\section{Conclusion}

Hopefully this brief contribution may stimulate further research in the theory of presuppositions. The themes and problems emerging in the pages above may also indicate some of the avenues of this research.

In the meantime, I hope this brief historical survey may be of some help to readers who are not familiar with this particular philosophical tradition. For those readers, this survey may also constitute an introduction to Elaine Botha's work, for knowing the tradition better should also help understanding her work better. To those, on the other hand, who are already well acquainted with neo-Calvinist philosophy, I would like to suggest that Botha's work has not yet re- 
ceived the attention it deserves. There is an opportunity to discover new riches of the Kuyperian legacy.

\section{List of references}

BOTHA, M.E. 1993. The mediating role of metaphor and analogy in the relationship between science and religion. Tydskrif vir Christelike wetenskap, 29(3):36-50.

BOTHA, M.E. 1996. Science, myth and metaphor. (In Blomberg, D., ed. Human being: essays dedicated to Stuart Fowler. Melbourne: Association for Christian Scholarship. p. 39-67.)

BOTHA, M.E. 2002. Of light and limits: philosophy matters. Koers, 36(2):207225.

BOTHA, M.E. 2006. Metaphor, embodiment and fiduciary beliefs in science. Tydskrif vir Christelike wetenskap, 42(Spesiale uitgawe 1):17-36.

BOTHA, M.E. 2007. Metaphor and its moorings: studies in the grounding of metaphorical meaning. Bern: Peter Lang.

CLOUSER, R.A. 1991. The myth of religious neutrality: an essay on the hidden role of religious belief in theories. Notre Dame: University of Notre Dame Press.

COLETTO, R. 2007. Presuppositions and the challenge to objectivity in latemodern philosophy of science: causes and possible remedies. Koers, 72(4):583-602.

COLETTO, R. 2009. Wolterstorff's critique of the reformational view of scholarship in his essay On Christian learning. Koers, 74(3):387-407.

COLETTO, R. 2010a. Interaction and antithesis in reformational scholarship. Acta academica, 42(1):1-25.

COLETTO, R. 2010b. The role of the Bible in reformational philosophy: historical and systematic notes. In die Skriflig, 44(3 \& 4):545-564.

DOOYEWEERD, H. 1959. Cinq conferences. La revue réformée, 10(3):3-76.

DOOYEWEERD, H. 1966. Het oecumenisch-reformatorisch grondmotief van de wijsbegeerte der wetsidee en de grondslag van de Vrije Universiteit. Philosophia reformata, 31(1 \& 2):3-15.

DOOYEWEERD, H. 1980. In the twilight of western thought. Nutley: Craig.

DOOYEWEERD, H. 1984. A new critique of theoretical thought. 4 vols. Jordan Station: Paideia.

DUVENAGE, B. 1985. Christian scholarship as Word-bound scholarship. Potchefstroom: Potchefstroom Studies in Christian Scholarship.

FRAME, J.M. 1987. The doctrine of the knowledge of God. Phillipsburg: Presbyterian and Reformed Publication Company.

GEERTSEMA, H.G. 1987. Christian philosophy: transformation or inner reformation? Philosophia reformata, 52(2):139-165.

HART, H. 1983. The articulation of belief: a link between rationality and commitment. (In Hart, H., Van der Hoeven, J. \& Wolterstorff, N.P., eds. Rationality in the Calvinian tradition. Lanham: University Press of America. p. 209-248.)

HART, H. 1985. Dooyeweerd's Gegenstand theory of theory. (In McIntire, C.T., ed. The legacy of Herman Dooyeweerd. Lanham: University Press of America. p. 143-166.) 
HART, H. 1988. The idea of an inner reformation of the sciences. (In Marshall, P.A. \& Vander Vennen, R., eds. Social sciences in Christian perspective. Lanham: University Press of America. p. 13-31.)

KLAPWIJK, J. 1984. Religieuse antithese en teoretishe communicatie in de sociale wetenschappe. Radix, 10(1):153-168.

KLAPWIJK, J. 1986. Antithesis, synthesis and the idea of transformational philosophy. Philosophia reformata, 51(1-2):138-152.

KLAPWIJK, J. 1987. Reformational philosophy on the boundary between the past and the future. Philosophia reformata, 52(2):101-134.

KLAPWIJK, J. 2008. Purpose in the living world? Creation and emergent evolution. Cambridge: Cambridge University Press.

KOK, J.A. 1988. Vollenhoven and scriptural philosophy. Philosophia reformata, 53(2):101-142.

OLTHUIS, J.H. 1989. On worldviews. (In Marshall, P.A., Griffioen, S., \& Mouw, R.J., eds. Stained glass: worldviews and social science. Lanham: University Press of America. p. 41-55.)

POLANYI, M. 1946. Science faith and society. Chicago: University of Chicago Press.

STAFLEU, M.D. 1987. Theories at work: on the structure and functioning of theories in science, in particular during the Copernican revolution. Lanham: University Press of America.

STRAUSS, D.F.M. 2009. Philosophy: the discipline of the disciplines. Grand Rapids: Paideia Reformational Project.

VAN DER WALT, B.J. 2008. The eye is the lamp of the body: worldviews and their impact. Potchefstroom: The Institute for Contemporary Christianity in Africa.

VAN RIESSEN, H. 1973. Science between presuppositions and decisions. Philosophia reformata, 38(1):114-126.

VANDER STELT, J.C. 1990. Philosophical assumptions in North-American presbyterian theology. Pro Rege, 18(4):9-19.

VENTER, J.J. 1994. Reformational university basis in operation. Orientation, $(71-74): 260-294$.

VOLLENHOVEN, D.H. Th. 1953. Schriftgebruik en wijsbegeerte. Mededeelingen van de Vereeniging voor Calvinistische Wijsbegeerte, Sept. 6-9.

VOLLENHOVEN, D.H. Th. 1992. Schriftgebruik en wijsbegeerte. (In Tol, A., Bril, K.A., eds. Vollenhoven als wijsgeer: inleidingen en teksten. Amsterdam: Buijten \& Schipperhijn. p. 97-106.)

WOLTERS, A.M. 1989. On the idea of worldview and its relation to philosophy. (In Marshall, P.A., Griffioen, S. \& Mouw, R.J., eds. Stained glass: worldviews and social science. Lanham: University Press of America. p. 14-25.)

WOLTERSTORFF, N.P. 1976. Reason within the bounds of religion. Grand Rapids: Eerdmans.

WOLTERSTORFF, N.P. 1980. Educating for responsible action. Grand Rapids: Eerdmans.

WOLTERSTORFF, N.P. 1989. On Christian learning. (In Marshall, P.A., Griffioen, S. \& Mouw, R.J., eds. Stained glass: worldviews and social science. Lanham: University Press of America. p. 56-80.)

WOLTERSTORFF, N.P. 2004. Educating for shalom: essays on Christian higher education. Grand Rapids: Eerdmans. 
WYKSTRA, S.J. s.a. Religious beliefs and metaphysical beliefs: the distinction and its importance for understanding past and present science. Grand Rapids: Calvin College.

\section{Key-concepts:}

Christian scholarship

Kuyperian tradition

presupopsitional frameworks

presuppositions, prescientific

theorising, scientific

\section{Kernbegrippe:}

Christelike wetenskap

Kuyperiaanse tradisie

vooronderstellings, voorwetenskaplike

vooronderstellingsraamwerke

teoretisering, wetenskaplike 